\section{PLASTIK FILM SEBAGAI PENGEMAS MAKANAN ASINAN JAHE UNTUK EKSPOR}

Oleh : Prayitno, Any Setyaningsih

\section{ABSTRACT}

One of the plastic material which is usually used for packaging polyethylene. That plastic has a good performance for plasticity, chemica resistance. flexibility and no toxic subtances, therefore, this is suitable for goo packaging. One of the use plastic film for packaging is for packing of salted ging for export purpose. Research in physical properties of the salted ginger paackagin shows that plastic film packaging has a weakness in the tearing strength propertic and some leaking caused by the unproper sealing during the process.

\section{INTISARI}

Salah satu bahan plastik yang banyak digunakan untuk bahan pengema adalah bahan plastik polyethylena. Bahan tersebut mempunyai sifat yang baik dalan keuletan, ketahanan terhadap bahan kimia serta fleksibilitasnya dan tida mengandung bahan-bahan yang toxic sehingga sangat cocok untuk pengema makanar. Penggunaan kantong plastik film polyethylena untuk pengemas makanal diantaranva untuk mengemas bahan setengah jadi asinan jahe untuk keperlua ekspor. Dari hasil penelitian sifat fisis kantong plastik untuk kemasan asinan jah masih dijumpai adanya kelemahan pada bahan piastiknya, yaitu pada kekuata sobeknya dan kebocoran-kebocoran yang sering terjadi yang disebabkan kuran sempurnanya dalam pembuatan kantong plastik, terutama dalam proses lekat pana

\section{PENDAHULUAN}

Bahan plastik merupakan bahan polimer sintetis yang terdiri dari moleku molekul yang merupakan rangkaian beribu-ribu satuan yang dinamakan monome panjang pendeknya rangkaian molekul polimer akan membedakan sifat-sifat fisil dahi bahan plastiknya. Bahan-bahan plastik dibedakan dari jenis monomerny sebagai contoh dikenal Poly Vinyl Chlorida (PVC) dimana merupakan rangkai dari monomer Vinyl Chlorida, bahan plastik polyethylena (PE) adalah bahan plasti yang tersusun dari monomer Ethylena.

Untuk setiap jenis bahan plastik mempunyai kekhususan dalam sifat-sifatny Salah satu bahan plastik yang banyak digunakan untuk bahan pengemas adala bahan plastik polyethylena. Bahan plastik tersebut mempunyai keunggulan dalar
Luhiati hatahanan terhadap bahan kimia serta fleksibilitasnya, dan tidak (II Heinikime bahan-bahan yang membahayakan, sehingga sangat cocok untuk

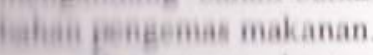

(

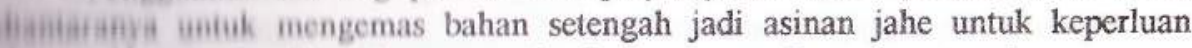

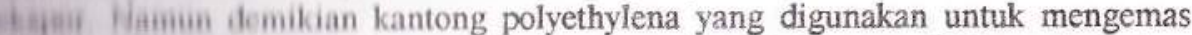
thinit jaie terebot masih banyak terjadi kebocoran-kebocoran. Hal tersebut akan Iunif memamakan mutu dari produk yang dikemas. Untuk itu perlu kiranya Wiakitaih litenifikasi terhadap terjadinya kebocoran tersebut dan dicari alternatif ata Biemeatasimvs

1нiнan disi studi ini adalah untuk mendapatkan beberapa arternatif untuk

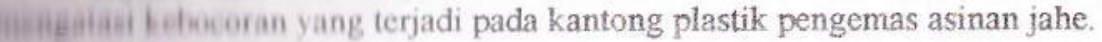

\section{TINJAUAN PUSTAKA}

I Ain demsity Polyethylena merupakan bahan plastik yang banyak digunakan

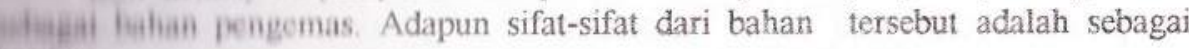
Initiii

\section{hinekise}

I aw density polyethylena terdiri dari 50-60\% kristal padat, tidak leleh biha whii $+115^{\circ} \mathrm{C}$ dengan berat jenis antara $0,91-0.94$, larut dalam beberapa if pelami pada temperatur diatas $100^{\circ} \mathrm{C}$, tetapi tidak larut dalam zat pelarut timetait pada suhu kamar

Gind our bimia

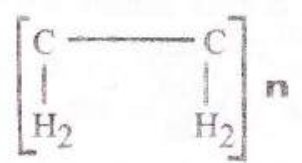

bifat bisin

Hifit sifat fisis dari polyethylena adalah fungsi dari tiga susunan variabel fiefai melekul distribusi dan cabang rantai panjang atau pendek. Cabang rantai

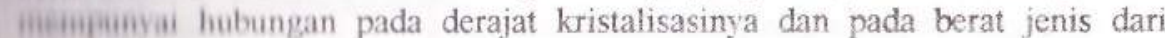
peibulivena, karena itu polyethylena sangat bergantung pada kristalisasinya (ue iii sifai kekakuan, ketahanan sobek, kekerasan dan ketahanan terhadap Hinii Ketahanan suhu bertambah dengan bertambahnya berat jenis atau

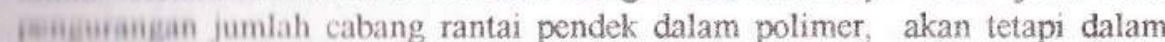
init permiability terhadap uap air dan gas juga dalam hal sifat-sifat, keuletan dan hilemiнan akan berkurang. Perpanjangan putus dari polvethylena sangat ferigaiung pada Melt Flow Index (MFI) serta density dari bahan plastiknya, whak in kecil MFI dan densitynya bahan akan menjadi semakin liat 
Temperatur proses untuk polyethylena sangat bervariasi bergantung pada polymerisasi serta proses yang digunakan, pada umumnya berkisar antara $140^{\circ} \mathrm{C}$ sampai $300^{\circ} \mathrm{C}$

Untuk film digunakan polimer yang mempunyai sifat ulet dan film yan fleksibel. Perpanjangan putus dari polyethylena sangat bergantung pada density dengan lebih tingginya derajat kristalisasinya, bahan dengan density tinggi akan menjadi berkurang pembuluhnya sehingga bahan menjadi getas. Sifat liat dari getas sangat bergantung pada nilai melt flow index dan densitynya. semakin kecil nilai melt flow index, sifat liat kan menjadi semakin besar dengan turunny density

Temparatur proses untuk polyethylena sangat bervariasi tergantung $\mathrm{d}$ polimer vang dipergunakan, pada umumnya berkisar antara $140^{\circ} \mathrm{C}$ sampa $300^{\circ} \mathrm{C}$

\section{Sifat Kimia}

Ketahanan kimia dari polyethylena adalah kira-kira sama dengan bah paraffin. Pada suhu kamar tidak ada bahan pelarut yang bisa melarutka polyethylena. Polimer dengan density yang rendah akan larut dalam benzen pada suhu $60^{\circ} \mathrm{C}$. Low density polyethylena mempunyai sifat permeabilit terhadap gas, diperkirakan sama dengan bahan-bahan bersifat seperti kare (rubery material). Pada suhu $30^{\circ} \mathrm{C}$, tebal $1 \mathrm{~mm}$ dan luas $1 \mathrm{~cm}^{2}$, pada tekanan $\mathrm{mm} \mathrm{Hg}$.

Polyethylena dengan density 0,922 mempunyai permeability terhadap $\mathrm{N}_{2}=19 \times 10^{-10} \mathrm{~cm}^{3} /$ det

$\mathrm{O}_{2}^{2}=55 \times 10^{-10} \mathrm{~cm}^{3} /$ det

$\mathrm{CO}_{2}=352 \times 10^{-10} \mathrm{~cm}^{3} / \mathrm{det}$

dan permeability terhadap uap air pada kelembaban $90 \%$ suhu $25^{\circ} \mathrm{C}=800 \times 10^{-10} \mathrm{~cm}^{3} / \mathrm{det}$

Polyethylena karena pengaruh sinar matahari dan oksigen akan kehilanga regangan, perpanjangan putus dan ketahanan sobek. Hal ini kemungkinan sin matahari dan oksigen menyerang hidrogen tersier pada titik rantai caban Pengaruh stabiliser terhadap polyethylena memperlambat kerusakan, tetapi tida banyak stabiliser yang sesuai untuk polimer ini. Sedangkan pengaruh pigmen carbon black terhadap ketahanan cuaca sangat baik. Polimer ini jug mengalami banyak ikat silang (cross linking) bilamana dipanaskan dikerjakan pada suhu yang tinggi.

\section{Maien}

Hatami jelakmanan studi ini, diambil kantong pengemas untuk asinan jahe

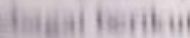

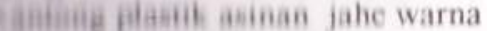

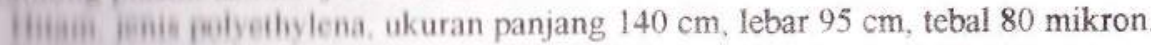

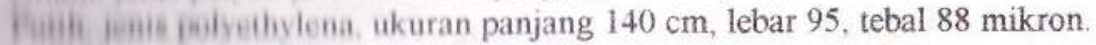

\section{Minimis}

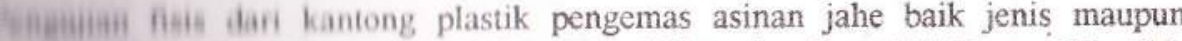
(uiaina ilumaikan dengan SII. 0250 - 79 : "Mutu dan Cara Uji Karung Plastik",

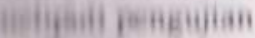

Paising tetar serta tobal

(1umen itain jlaslik sebelum diuji dikondisikan dahulu pada suhu ruangan $23^{\circ} \mathrm{C}$ 1 fHi dian helembaban relatip $60 \% \pm 2 \%$, selama 24 jam.

Heisenan plisstik ditempatkan ditempat datar sehingga rata.

fenfani jengemas diukur dari mulut pengemas sampai dasar perekatan.

( G his fwememas adalah jarak antara kedua sisi, diukur pada dasarnya.

I tiaf likit panas diukur pada bagian yang dikenakan lekat panas.

Cinit litil dan Kemuluran

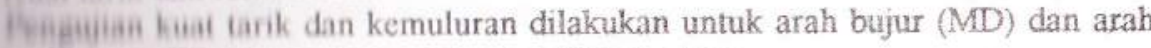
iini inianie (11)) dan pada bagian yang dilekat panas

flicat inaioh bentuk dayung.

I umitisik am pada kondisi ruangan standart selama 24 jam.

f inish dijepit antara dua penjepit pada alat uji kuat tarik dengan jarak jepit fis $1+\mathrm{im}$

I thikan jenarikan

$$
\text { fuat fark }=\frac{\mathrm{P}}{\mathrm{L} \times \mathrm{t}} \mathrm{kg} / \mathrm{cm}^{2}
$$

IHimane $\mathrm{F}-$ Beban tarikan $(\mathrm{kg})$

1. - I ebar contoh $(\mathrm{Cm})$

1 - Tebal contoh $(\mathrm{Cm})$

IiI I/ No 21 Tahun 19951996
75 
Kemuluran $=\frac{\mathrm{L}_{1}-\mathrm{L}_{0}}{-\cdots}$

$\mathrm{x} 100 \%$

$\mathrm{L}_{0}$

Dimana $: \mathrm{L}_{1}=$ Panjang saat putus

$\mathrm{L}_{0}=$ Jarak jepit mula-mula

c. Kuat Sobek.

Uji kuat sobek dilakukan untuk arah melintang (TD) atau membujur (MD).

- Buat contoh uji untuk kuat sobek.

- Setelah dikondisikan dalam ruang kondisi standar dilakukan pengujian sobek dengan alat uji kuat sobek.

Kuat Sobek $=\frac{P}{-A^{-2}} \mathrm{~kg} / \mathrm{Cm}^{2}$

Dimana $: \mathrm{P}=$ Beban terbaca pada skala $(\mathrm{kg})$

\section{HASIL PENGUJIAN DAN PEMBAHASAN}

\section{Hasil pengujian}

Hasil uji dibandingkan dengan SII.0250-79 : Mutu dan cara Uji Karu Plastik dapat dilihat pada tabel berikut :

\begin{tabular}{|c|c|c|c|c|c|}
\hline \multirow[t]{2}{*}{ linisitili } & \multirow[t]{2}{*}{ Satuan } & \multicolumn{2}{|c|}{ Hasil Uji } & \multirow[t]{2}{*}{ Syarat SII } & \multirow[t]{2}{*}{$\begin{array}{c}\text { Perkiraan } \\
\text { untuk beban } \\
75 \mathrm{~kg}\end{array}$} \\
\hline & & Hitam & Putih & & \\
\hline I fitit & $\mathrm{cm}$ & 95 & 95 & Min. 59 & - \\
\hline Санiatis & $\mathrm{cm}$ & 140 & 140 & Min 118 & - \\
\hline Ithal & mikron & 80 & 88 & Min . 45 & - \\
\hline 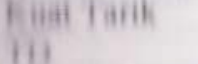 & $\mathrm{kg} / \mathrm{cm}^{2}$ & 12765 & 182.77 & Min 100 & $\operatorname{Min} 150$ \\
\hline (iii) & & 238,07 & 239,21 & Min. 160 & Min. 240 \\
\hline Bhilias & $\%$ & & & & \\
\hline 111 & & 315 & 409,38 & $\operatorname{Max} 280$ & - \\
\hline (iil) & & 393,44 & 394,04 & $\operatorname{Max} 150$ & - \\
\hline f biar bathel & gram & & & Min 256 & $\operatorname{Min} 384$ \\
\hline 111 & & $\begin{array}{l}709,43 \\
158,33\end{array}$ & $\begin{array}{l}109,43 \\
158,33\end{array}$ & Min 141 & $\begin{array}{l}\text { Min. } 384 \\
\text { Min } 211\end{array}$ \\
\hline I liat baril ali & $\mathrm{Kg} / \mathrm{cm}^{2}$ & $\begin{array}{l}150,53 \\
126,67\end{array}$ & 115,15 & Min. 50 & Min. 75 \\
\hline fot at janas & & & & & \\
\hline $\begin{array}{l}\text { fotar lokat } \\
\text { fianas }\end{array}$ & $\mathrm{Cm}$ & 0,3 & 0,3 & Min. 0,2 & - \\
\hline
\end{tabular}

L Heisegen 10 - arah melintang $\mathrm{MD}$ = arah membujur

\section{Fyehahase}

Hain hasil wii fisika Kantong Plastik Pengemas Asinan jahe dibanding dengan

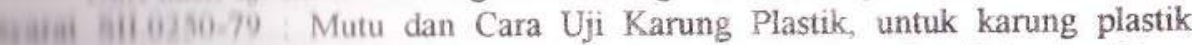
1. He man makiman sudah menunjukkan hasil jauh diatas persyaratan.

(1)iaik Kantong Plastik Pengemas Asinan jahe yang dibebani seberat $70 \mathrm{~kg}$. Whi lihitik pukiraan syarat mutunya dari SII.0250-79: Mutu dan Cara Uji karung

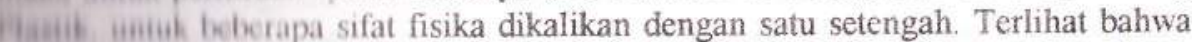
(1) Li je imaratan fisika dikalikan dengan faktor 1,5 ; semua persyaratan terlampaui Liaii jaidi hiai sobek untuk arah membujur. Hal tersebut dikarenakan film HDPE 11.

Halam makalah lembaran plastik dan penggunaannya yang disajikan oleh Iniai Tyenemdalian Mutu Petrokimia PERTAMINA disebutkan bahwa kuat sobek

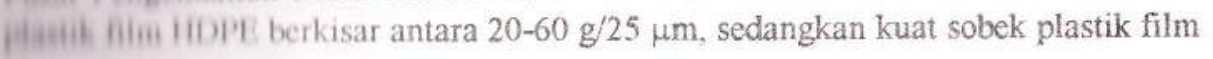


plastik film HDPE berkisar antara $20-60 \mathrm{~g} / 25 \mu \mathrm{m}$, sedangkan kuat sobek plastik film sar antara 200-300 g/25 um. Penambahan LDPE pada HDPE kemungkinan akan menaikkan sifat kuat sobek.

\section{KESIMPULAN}

Dari hasil pengujian-pengujian tersebut diatas dapat ditarik kesimpulan : kantong plastik untuk kemasan asian sobeknya pada bahan plastiknya, yaitu pada kekuata salah disebabkan kurang

2 Kebocoran-kebocoran yang sering torang plastik tersebut, terutama dalam proses empurnanya dalam pembuatan kantong plast lekat panas

\section{DAFTAR PUSTAKA}

Brydton J.A. (1975). Plastikc Material, Newest Brither Worth, London.

2. Departemen Perindustrian, SII $0250-79$ : Mutu dan Cara Uji Karung Plastik.

3. Fred W Billmeyer Jr. (1970), Text Book of Polvmer Science, New York

4. Richardson, Terry A., Modern Industrial Plastic, Haword W. Sons and Co. In Indiana Polis, Kansas City, New York. 